Валерія Скрипнікова, Національний університет оборони України імені Івана Черняховського, м. Київ

ORCID ID 0000-0002-0056-7299

DOI: $10.33099 / 2617-1775 / 2020-02 / 282-292$

\title{
РОЗВИТОК МІЖКУЛЬТУРНОЇ КОМПЕТЕНТНОСТІ У ПСИХОЛОГО-ПЕДАГОГІЧНІЙ ТЕОРІЇ І ПРАКТИЦІ (ЗАРУБІЖНИЙ ДОСВІД)
}

У статті розкрито особливості розвитку міжкультурної компетентності у праиях зарубіжних дослідників, зокрема американських та європейських. На основі аналізу та узагальнення поглядів сучасних зарубіжних науковців виокремлено технології навчання для ефективного розвитку міжкультурної компетентності. Актуалізовано необхідність вирішення проблеми розвитку міжкультурної компетентності майбутніх магістрів військового управління.

Вивчення зарубіжного досвіду свідчить про необхідність інтеграції міжкультурного (полікультурного) компонента у професійну підготовку військових фахівиів.

Ключові слова: міжкультурна компетентність; міжкультурна комунікація; міжкультурний діалог; міжкультурна взаємодія; полікультурна освіта; інтерактивні технології.

Постановка проблеми. Протягом останнього десятиліття учені 3 розвинених країн Європи та світу, зокрема Австрії, Великої Британії, Канади, Німеччини, Франції, Литви, Латвії на міжнародному рівні ведуть дискусію щодо надання людині можливості здобувати відповідні знання, вміння та компетентності, що забезпечать їі ефективну взаємодію з сучасним динамічним i технологічним суспільством. На сьогодні актуальності набуло питання підготовки особистості і розвитку у неї здатності ефективно і творчо діяти в умовах постійно змінюваного сучасного світу, що вимагає врахування національних та міжкультурних особливостей інших народів у процесі взаємодії.

Курс освітнього процесу на європейські концепції і цінності та поступовий перехід до глобального суспільства спрямовують систему підготовки майбутніх магістрів військового управління до інтеграції в міжнародні освітні програми та використання європейських стандартів, що визначає необхідність удосконалення діяльності закладів вищої освіти до їх фахової підготовки та спрямовує до пошуку інноваційних педагогічних технологій і форм навчальної роботи. Оскільки цей напрям є достатньо новим та малодослідженим, виникає необхідність вивчення передового досвіду розвинених країн світу й адаптації його в умовах України.

Отже, враховуючи вищезазначене, вважаємо, що на сьогодні актуальним є вивчення зарубіжного досвіду розроблення теоретичних положень i відповідних практик для пошуку методів та шляхів удосконалення навичок міжкультурної компетентності. 
Набуття міжкультурної компетентності виступає своєрідним «гарантом» подолання етнічних, мовленнєвих, культурних бар'єрів у процесі міжкультурного діалогу, міжкультурної комунікації під час роботи міжнаціональних об'єднаних штабів, ділових переговорів, міжнародних презентацій, конференцій, брифінгів, виставок тощо. Щоб вдосконалити вітчизняну вищу військову освіту вважаємо за доцільне звернутися до зарубіжного досвіду 3 метою запровадження й адаптації практик та інноваційних педагогічних технологій у систему вищої військової освіти.

Метою статті $\epsilon$ аналіз зарубіжного досвіду розвитку міжкультурної компетентності у психолого-педагогічній теорії і практиці, а на його основі визначення шляхів впровадження моделей розвитку міжкультурної компетентності в науковий обіг України i виокремлення критеріїв міжкультурної компетентності, що потребують подальшого розвитку.

Завдання статті на основі теоретичного аналізу особливостей розвитку міжкультурної компетентності у педагогічній теорії і практиці провідних країн світу запропонувати можливі підходи до їх імплементації в українську військово-педагогічну науку.

Методи дослідження: теоретичні - аналіз, синтез, узагальнення та систематизація наукових розвідок зарубіжних публікацій, порівняння, систематизація, системно-структурний аналіз для обгрунтування змісту i структури міжкультурної компетентності.

Виклад основного матеріалу. Аналіз останніх зарубіжних досліджень показує, що у науковій літературі питання міжкультурної компетентності переважно розглянуто як науково-педагогічну проблему (M.Byram, C.Bennett, D.Deardorff, J.Knight, K.Knapp, C.Kramsch, A.Moosmüller, О.Зеліковська, І.Плужник). Серед зарубіжних дослідників привертають увагу Е.Хол, О.Садохін (висвітлили виклики, які виникають під час взаємодії 3 представниками інших культур), В.Біблер (вивчав особливості міжкультурної компетентності з точки зору діалогу культур), Т.Самохіна, С.Тер-Мінасова, Е.Хол (розглядали можливість розвитку та формування міжкультурної компетентності шляхом підготовки програм 3 міжкультурної комунікації). Міжкультурна компетентність $є$ об'єктом наукових досліджень багатьох зарубіжних дослідників зокрема, Еверет М.Роджерс, М.Бірам, Дж.Беннет, К.Беннет, В.Гудикунст, Б.Траггер, Г.Хофстеде ( аналіз моделей міжкультурної компетентності), Д.Річардсон (теорії адаптації особистості до іншого культурного середовища).

Проблема розвитку міжкультурної компетентності залишається актуальною не тільки у сфері міжнародної дипломатії та туризму. На сьогодні вона актуальна для представників сфери освіти й науки, соціальної i правоохоронної сфер, військових керівників та військової сфери загалом, майже для кожного, хто живе в час глобалізаційних перетворень у полікультурному суспільстві.

Аналіз зарубіжного досвіду засвідчує, що де які західноєвропейські університети наприкінці XX ст. почали впроваджувати в освітні програми навчальні курси 3 міжкультурної комунікації. На основі американського 
досвіду викладання міжкультурної комунікації були розроблені навчальні програми, які базуються на матеріалах етнології, лінгвістики і фольклористики.

На сьогодні ефективне застосування програм міжкультурного тренінгу, тренінгів міжкультурної комунікації, взаємодії, що зосереджують увагу на усвідомленні особистої належності до певної групи або культури 3 метою формування (розвитку) міжкультурної компетентності, спрямовані не тільки на усвідомлення цінності власної культури, а й на аналіз розбіжностей між культурами. Як наслідок, відбувається набуття вмінь та навичок так званого проникнення у визначені культурні відмінності для підвищення ефективності взаємодї.

Процеси формування єдиного освітнього європейського простору вищої освіти, що нині тривають, є значущими і для України. «Чим більше вплине інтернаціоналізація на підвищення рівня відкритості української системи вищої освіти, тим легше i швидше перетворення зможуть прижитися» [2, с.38]. Найважливішими завданнями національних систем освіти за компетентнісною концепцією ЮНЕСКО визначено такі: «навчитися жити разом», «навчитися пізнавати», «навчитися робити» $\mathrm{i}$ «навчитися бути» [3, с.41]. Саме ці життєвоважливі компетентності мають впливати на формування відповідних освітніх цілей, на реалізацію яких слід спрямовувати сучасну освіту. Чітке виокремлення чотирьох освітніх цілей, покладених в основу освітнього процесу, впливає на професійний розвиток і на саме життя, тому розвиток цих компетентностей має стати пріоритетом сучасної вищої освіти. Аналіз історії зарубіжного досвіду показує, що після Другої світової війни США почали впроваджувати низку програм, спрямованих на допомогу у відновленні країн, які зазнали значних втрат внаслідок війни. Багато 3 цих програм виявились неефективними, через неврахування під час розроблення проєктів культурних особливостей країн (специфіку політичної, економічної, технічної структури) стали причиною та наслідком зазначених невдач [7, с. 59-62]. С підстави вважати, що саме повоєнні події поклали початок дослідженням питань міжкультурної комунікації та, відповідно, міжкультурної компетентності.

Видання у 1946 році Конгресом США указу про створення Інституту дипломатичної служби, де мали працювати лінгвісти й антропологи, що забезпечували підготовку працівників дипломатичних служб до початку і під час роботи, стало потужним поштовхом у вивченні і розвитку досліджуваного питання. Одним із провідних антропологів Інституту був Е.Хол, який визначив поняття «міжкультурна комунікація», а виникнення самого терміна «міжкультурна компетентність» відбулося в ході вивчення особливостей міжкультурної комунікації та після виходу у світ книги Е.Хола та Б.Траггера «Culture as Communication a Model and Analysis» («Культура як комунікація: модель аналізу») привело до виведення ii в окрему дисципліну. Основні положення та ідеї міжкультурної комунікації, а саме аналіз невербальної комунікації, детально було викладено у відомій праці Е.Хола «The Silent Language» («Німа мова») (1959) [16]. Автор ретельно відстежив тісний зв'язок між культурою і комунікацією та наголосив на необхідності навчання культурі спілкування $з$ іншими народами («якщо культуру можна вивчати, це означає, 
що iï можна викладати»). Отже, дослідження міжкультурної компетентності започаткували американці, які на цей час розрізняють міжкультурну компетентність у двох вимірах - змістово орієнтовану та орієнтовану на процес.

Змістово орієнтована міжкультурна компетентність є одновимірною, тобто статичною (стосується знань про різні культури, у тому числі власну національну, загальних мовленнєвих навичок, знань міжособистісних кодексів етики, поведінки, обізнаності про соціоекономічні умови, в яких проживають люди). Формування змістово орієнтованої міжкультурної компетентності відбувається у процесі формальної освіти або професійного навчання.

Процесно орієнтована міжкультурна компетентність $є$ динамічною формується у процесі застосування інтерактивних технологій і комунікативних тренінгів та поділяється на такі підгрупи:

- інтеракційні - сенситивність до культурних відмінностей у комунікативних ситуаціях, здатність виявляти та інтерпретувати крос-культурні варіативності);

- когнітивні - здатність оцінювати культурний багаж співрозмовника та вміння використовувати його для вирішення проблемних ситуацій;

- емотивні - навички автотренінгу та самопізнання особистістю реакцій у міжкультурному спілкуванні;

- дискурсивні - обізнаність у дискурсі міжкультурного різноманіття, міжкультуральності та міжкультурних відмінностей) [8].

Програми, спрямовані на розвиток міжкультурної компетентності у США, містять такі компоненти: етно- i соціокультурні знання, що охоплюють психологічний рівень; соціальні знання та саморефлексія, що охоплюють особистісний рівень; розвиток мовленнєвих умінь, навичок; культурна компетентність у сфері прав людини. Застосування тренінгів, інтерактивних технологій для розвитку міжкультурної компетентності спрямовані насамперед на тренування невербальної поведінки (декодування чужих вербальних кодів, невербальних символів та використання їх у власній комунікативній діяльності), тренування креативності, відмови від стереотипних варіантів реагування на ситуації, тренування сенситивності, емпатії [ 9].

Загальною проблемою вважаються культурні непорозуміння, зумовлені тим, що комунікант (відправник) повідомлення складає або «кодує» в одному культурному контексті, а комунікат (отримувач) потім отримує і «декодує» їх в іншому культурному контексті [13]. Саме так поширюються культурні переконання та правила, що призводять до розбіжностей у поведінці [12; 14]. Дослідження особливостей формування міжкультурної компетентності студентів немовних вузів засобами сучасних інформаційно-комунікаційних технологій показало, що міжкультурною компетентністю слід вважати володіння певною сукупністю знань про культуру країни, мову якої вивчають, що забезпечує культурну взаємодію [1]. Для розвитку міжкультурної компетентності у процесі здобуття вищої освіти застосовують такі методи навчання і набуття практичного досвіду: вивчення періодики, преси, перегляд документальних, науково-популярних і художніх фільмів, перегляду та аналізу 
останніх новин (CNN, BBC, EuroNews); порівняння й обговорення міжкультурних особливостей; встановлення контакту; обговорення та розгляд конкретних проблем; вивчення стилістичних особливостей мови; аналіз прислів'їв, метафор, асоціацій що функціонують у культурному середовищі; обговорення та аналіз особливостей виступів політичних діячів різних країн.

Освітні програми 3 питань формування (розвитку) міжкультурної компетентності у США також спрямовані на здобуття студентами знань 3 питань культурної ідентичності, глобального громадянства, етнічної спільності тощо.

Значний внесок у дослідження міжкультурної комунікативної компетентності зробив американський учений К.Беннет. Він зазначає, що мова перебуває в центрі культури і пізнавальної здатності; ефективність міжкультурного спілкування людей можна удосконалити завдяки розвитку та розширенню культурної обізнаності, а саме здатності розпізнавати культурні відмінності у власному сприйнятті; існують певні типи людської поведінки, які оминають фахові бар'єри; категорії існування різних культур в одному суспільстві $\epsilon$ достатньо статистично підтвердженими, щоб бути ідентифікованими, визначеними і стати аспектом вивчення; індивіди можуть утримувати психологічний баланс між гордістю за свою культуру та повагою до інших культур [10, с. 294].

Зазначимо, що основою ефективного розвитку міжкультурної компетентності, на думку американських дослідників, $є$ знання мови, культурна обізнаність, визнання культурних відмінностей, культурних переконань, поведінки й етики. У процесі інтеракцій студенти набувають здатності виявляти культурні відмінності, оцінювати і вирішувати проблемні ситуації, запобігати конфліктам, відпрацьовують навички самопізнання, рефлексії, стають обізнаними у сфері міжкультурних відмінностей.

У Європі становлення міжкультурної комунікації відбувалося пізніше, ніж у США. Проблеми міжкультурної компетентності дослідники почали опрацьовувати, коли виникла теоретико-практична потреба досягнути взаєморозуміння між народами, життєвий уклад яких різко відрізнявся. 3 формуванням європейського співтовариства як відкритого для вільного переміщення людей, капіталів і товарів, виникненням конфліктів, пов'язаних із появою великої кількості емігрантів, їх інтеграцією в європейський культурний простір поступово почав формуватися інтерес науковців до міжкультурного спілкування. Сучасні дослідження були започатковані наприкінці 1980 рр. Як зазначив професор Мюнхенського університету К.Рот «треба констатувати, що етнографія (і не тільки в Німеччині) до цього часу не вивчала безпосередньо проблему міжкультурної компетентності і контакт культур на підприємствах». В дослідженнях залежно від мети головну увагу приділяли аспектам сприйняття, поведінки і мовленнєвих відмінностей [15]. 3 того часу почали розробляти освітні програми, що базуються на матеріалах фольклористики, етнології і лінгвістики.

На думку німецьких учених, перебування у середовищі іншої культури сприяє розвитку фахової, соціальної та інтеркультурологічної (міжкультурної) 
компетентностей завдяки здобуттю нових i поглибленню наявних знань 3 іноземних мов, сприянню розвитку гнучкості та здатності до співпраці, налаштуванню на ефективне спілкування, розумінню інших культур i менталітету, ознайомленню із закордонними ринками, оволодінню фаховими знаннями. Як відомо, мова виступає засобом відображення усіх сфер життя суспільства, його історії, культури, звичаїв, вірувань і цінностей. Саме тому вивчення мови як віддзеркалення свідомості суспільства допомагає ознайомлюватися 3 усіма тонкощами комунікації в новому мовленнєвому середовищі, подолати «зіткнення культур», розуміти фразеологізми, адекватно застосовувати невербальну мову. Процеси поглиблення міжнародних зв'язків, уможливлення спілкування, ознайомлення 3 культурними традиціями та особливостями держави, у якій навчаються іноземці, значно пришвидшують i полегшують процес адаптації. Так, М.Бірам вважав, що формування міжкультурної компетентності - це опанування методів аналізу міжкультурної комунікації як допоміжного інструменту для орієнтування в ситуаціях, які неможливо передбачити, та можливості сприймати і відображати суспільство не тільки крізь призму культури домінуючої еліти [6].

Німецькі науковці G.Auernheimer, S.Hildegard зазначають, що розвиток міжкультурної компетентності відбувається на базі професійної діяльнісної компетенції та $\epsilon$ сукупністю аналітичних i стратегічних здібностей, які розширюють інтерпретаційний спектр індивіда у процесі міжособистісної взаємодії з представниками інших культур. Так, G.Auernheimer наголошує, що розвиток міжкультурної компетентності слід починати 3 самоаналізу та критичної саморефлексії. Автор виокремлює такі складові міжкультурної компетентності: адекватне сприймання та інтерпретація культурних цінностей; уникання розмежування культур, вміння знаходити спільне і відмінне в різних культурах; позитивне сприйняття різних культурних явищ та представників інших культур; розширення досвіду міжкультурного спілкування; розуміння теорії і практики міграції як феномену сучасного суспільства; розрізнення понять культурної ідентичності та міграції; здобуття нових знань про іншу культуру для глибшого пізнання власної; узагальнення власного досвіду у міжкультурному діалозі [3, с.33-34].

В дослідженнях М.Бірама [5] наголошено, що взаємодія різних мов i культур пришвидшує розвиток міжкультурної компетентності. Під час взаємодії розвиваються набута компетентність із застосування соціальних правил (мови та жестів, відповідних комунікативних знань, мотивації спілкування, методу визначення соціально-культурних знань) i здатність нешаблонно реагувати в нестандартних комунікативних ситуаціях. Цей процес містить дві змінні величини: здатність до прояву вищого комунікативного статусу і систему доцільної (виправданої) компетенції, основу становить якість комунікації

Досліджуючи проблеми полікультурної освіти у працях польських педагогів, С.Сисоєва зазначає, що у Республіці Польща полікультурну освіту розглядають як принцип освітньої політики, що відображає неминучість співіснування людей 3 різними культурами, толерантне ставлення до 
особливостей іншої культури та ії представника. Мета міжкультурної освіти полягає у формуванні знань, умінь якостей і поведінкових характеристик особистості, які забезпечують іiі толерантність до відмінностей, відкритість до діалогу, здатність ефективно взаємодіяти із представниками іншої культури. Міжкультурність (інтеркультурність) може бути реалізована, коли представники різних культур, національні, етнічні та релігійні групи тощо живуть на одній території, відкрито і регулярно взаємодіють, толерантні, розуміють особливості стилів життя, цінності, норми один одного [4].

Вивчення, компаративного аналізу науковців із Литви R.Kriaučiūnienè, A.Šiugždinienè [11] щодо розвитку міжкультурної комунікативної компетентності, проведеного у процесі навчання англійської мови, показало, що найпопулярнішими виявилися види діяльності, спрямовані саме на знання та пізнання культури. Значний інтерес викликали питання цінностей і вірувань народів іншої культури (дуже часто й часто - $16,1 \%$ ), а ось набуття фактичних знань про географію іншої країни виявилися недостатньо цікавими $(12,7 \%)$ як і знання про політичну ситуацію (12,7\%). Показники рівня знань іншої культури виявилися занизькими через проведення недостатньої кількості практичних занять, спрямованих на розвиток міжкультурної компетентності [11, с. 99]. Обговорення питань, пов'язаних із повагою представників інших/відмінних культур (27,1\%), повагою до власної культури $(25,9 \%)$ і дискусії про власну культуру (25\%) стали найефективнішими. Крім того, дослідники провели опитування і виявили перелік тем, що потребують особливої уваги: навчання установленню міжкультурних контактів i сприянню комунікації, знання етикету інших культур, вияв власного ставлення до усних та письмових культурних відмінностей, вивчення власної культури, навчання способам сприяння вирішенню міжкультурних конфліктів, набуття навичок адекватного сприйняття культурних відмінностей, спроможності досягати порозуміння та врегульовувати міжкультурні конфлікти, тобто визначили перелік ключових компетенцій, що «розвивають здатність тих, хто навчається краще врегульовувати питання міжкультурної взаємодії» [11, с. 101].

Отже, бачення західноєвропейських дослідників формувалося під впливом американського досвіду, при цьому питання культури, розбіжностей у культурі і поведінці залишали на першому місці, але також були зосереджені на таких відмінностях у мові, фольклористиці, етнології. Розгляді способів запобігання конфліктам та їх вирішення тобто заглибленні саме в питання міжкультурної взаємодії і комунікації.

Аналіз зарубіжного досвіду показує, що нині, як в академічній, так і в діловій сфері триває пошук інструментарію вимірювання та оцінювання сформованості міжкультурної компетентності, а в освітній практиці - шляхів розвитку міжкультурної компетентності та оцінювання іiї ефективності, що дає підстави для таких висновків. 
1. За результатами теоретичного аналізу встановлено, що проблема міжкультурної компетентності на цей час $є$ надзвичайно актуальною і широко представлена в науковому дискурсі провідних країн світу, зокрема Австрії, Великої Британії, Канади, Німеччини, США, Польщі.

2. На підставі вивчення зарубіжного досвіду визначено, що питання міжкультурної компетентності майбутніх фахівців належить до компетенції закладів вищої освіти й має на меті набуття та розвиток таких навичок і умінь здобувачів освіти, які забезпечують їх ефективну комунікацію в інтеракційному (комунікаційному) процесі з представниками різних культур на мовленнєвому, дискурсивному, змістовому та поведінковому рівнях. Результатом такої взаємодії $є$ діалог культур та ефективна інтеграція культурних світоглядів.

3. Аналіз педагогічної практики формування міжкультурної компетентності показує, що для іiі розвитку доцільно використовувати інтерактивні технології, спрямовані на розвиток діалогічності, співробітництва, створення вільного творчого простору, самостійної активної пізнавальної діяльності, рефлексію, варіативність і гнучкість змісту навчання.

4. Сучасні військові фахівці для ефективної взаємодії у міжнародному середовищі безпеки повинні мати розвинуту міжкультурну компетентність, набуту у процесі професійної військової освіти, що забезпечує готовність до міжнародного співробітництва через знання типів культур, міжкультурних стилів комунікації, розрізнення мов і культур світу, володіння здатностями до міжкультурного розуміння та діалогу в полікультурному середовищі.

5. Аналіз зарубіжної військової практики показує, що сформована у слухачів (курсантів) міжкультурна компетентність створює передумови для гідних дій офіцерів на міжнародній арені, взяття активної участі у міжнародних військових навчаннях, семінарах, конференціях, нарадах тощо, у тому числі й без залучення перекладачів, що набуває особливої актуальності у наш час.

Перспективним напрямом подальших досліджень має стати обгрунтування моделі розвитку міжкультурної компетентності майбутніх магістрів військового управління Збройних Сил України в умовах змішаного навчання з використанням інтерактивних технологій.

\section{ЛІТЕРАТУРА}

1. Байбакова О. Формування міжкультурної компетентності майбутніх фахівців соціальної роботи у вищих навчальних закладах США: дис. канд. пед. наук. Ужгород, 2017.c.115-153.

2. Кнутсон С. Украина: новая реформа высшего образования и интернационализация / С. Кнутсон, В. Кушнаренко // Международное высшее образование. 2015. - № 79.- С. 36-38.

3. Сулима О. Компетентнісний підхід до підготовки педагогічного персоналу для дошкільних закладів ФРН: Методичні рекомендації, 2013.-с. 33-41.

4. Сисоєва С. Культурологічні концепти освітології та розвиток полікультурного суспільства// Неперервна професійна освіта. 2012. № 1-2.

5. Byram M., Zarate G. Investigating Cultural Studies in Foreign Language Teaching.Clevedon, Philadelphia, cop., 1991.

6. Byram M. Teaching and Assessing Intercultural Communicative Competence Multilingual Matters Ltd, 1997.-124 p. 
7. Everett M. Rogers, Thomas M. Steinfatt. Intercultural Communication. Waveland Press, Inc. Prospect Heights, Illinois, 1999.-59-62 p.

8. Stier J. Intercultural competencies as a mean stomanage intercultural interactionsin social work // Journal of Intercultural Communication. Issue 7, 2004.

9. Standards for Cultural Competence in Social Work Practice (2001) and Indicators for the Achievementofthe NASW Standards for Cultural Competence in Social Work Practice (2007).

10. Bennett Christine I. Comprehensive multicultural education: theory and practice. Boston: Allyn and Bacon, 1990.-P.294

11. Kriaučiūnienė R., Šiugždinienė A. Viewpoints of intercultural competence development in English language teaching/learning classroom. Kalbų didaktika. Iteikta, 2010.- P. 95-105.

12. Gray C. F. Project management: The managerial process. C. F. Gray, E. W. Larson. New York, NY: McGraw-Hill Education, 2014. P.68.

13. Rothlauf J. A global view on intercultural management: challenges in a globalized world. Walter de Gruyter GmbH \& Co KG, 2015.

14. Stawnicza O. Distributed team cohesion-not an oxymoron. The impact of information and communications technologies on teamness in globally distributed IT projects // International Journal of Information Systems and Project Management. 3. 2015. -№ 2. -p. 23-39.

15. Roth K. Interkultures Menegment-ein volkskundliches Problem. Zur interkulturellen Dimension von Wirtschaftsunter-nehmen//Der industrielle Mensch. Vortrage des 28. Deutschen Volkskundekongress in Hagen/Hg. M.Dauskardt/H. Gerndt.Hagen, 1991.

16. Hall E. The silent language. Garden City. N.Y.: Anchor,1959. - P. 217

\section{REFERENCES}

1. Baibakova O. (2017). Formuvannia mizhkulturnoi kompetentnosti maibutnikh fakhivtsiv sotsialnoi roboty u vyshchykh navchalnykh zakladakh SShA [ Formation of untercultural competence of future specialists of sjcial work in higher educational institution of the USA] dys. kand. ped. nauk. Uzhhorod. S. 115-153. (in Ukrainian).

2. Knutson S. (2015) Ukrayna: novaia reforma vыssheho obrazovanyia y ynternatsyonalyzatsyia [Ukraine new highter education reform and internationalization] / S. Knutson, V. Kushnarenko Mezhdunarodnoe vыsshee obrazovanye. № 79. S. 36-38. (in Ukrainian).

3. Sulyma O. (2013) Kompetentnisnyi pidkhid do pidhotovky pedahohichnoho personalu dlia doshkilnykh zakladiv FRN: Metodychni rekomendatsii, [Competence approach to the training of pedagogical staff for preschool institutions in Germany] s. 33-41. (in Ukrainian).

4. Sysoieva S. (2012) Kulturolohichni kontsepty osvitolohii ta rozvytok polikulturnoho suspilstva [Culturological concepts of edutology and the development of a multicultural society] Neperervna profesiina osvita. № 1-2. (in Ukrainian).

5. Byram M., Zarate G. (1991) Investigating Cultural Studies in Foreign Language Teaching. Clevedon, Philadelphia, cop. (in English).

6. Byram M. (1997) Teaching and Assessing Intercultural Communicative Competence Multilingual Matters Ltd, 124 p. (in English).

7. Everett M. Rogers, Thomas M. Steinfatt (1999) Intercultural Communication. Waveland Press, Inc. Prospect Heights, Illinois. 59-62 p. (in English).

8. Stier J. (2004) Intercultural competencies as a mean stomanage intercultural interactionsin social work / Journal of Intercultural Communication. Issue 7. (in English).

9. Standards for Cultural Competence in Social Work Practice (2001) and Indicators for the Achievementofthe NASW Standards for Cultural Competence in Social Work Practice (2007). (in English).

10. Bennett Christine I. (1990) Comprehensive multicultural education: theory and practice. Boston: Allyn and Bacon. P.294. (in English).

11. Kriaučiūnienè R., Šiugždinienè A. (2010) Viewpoints of intercultural competence development in English language teaching/learning classroom. Kalbų didaktika. Itteikta. P. 95-105. (in English). 
12. Gray C. F. (2014) Project management: The managerial process. C. F. Gray, E. W. Larson. New York, NY: McGraw-Hill Education. P.68. (in English).

13. Rothlauf J. (2015) A global view on intercultural management: challenges in a globalized world. Walter de Gruyter GmbH \& Co KG. (in English).

14. Stawnicza O. (2015) Distributed team cohesion-not an oxymoron. The impact of information and communications technologies on teamness in globally distributed IT projects // International Journal of Information Systems and Project Management. № 2. p. 23-39. (in English).

15. Roth K. (1991) Interkultures Menegment-ein volkskundliches Problem. Zur interkulturellen Dimension von Wirtschaftsunter-nehmen//Der industrielle Mensch. Vortrage des 28. Deutschen Volkskundekongress in Hagen/Hg. M.Dauskardt/H. Gerndt.Hagen.

16. Hall E. The silent language. Garden City. N.Y. Anchor,1959. - P. 217. (in English).

\section{РЕЗЮМЕ}

Валерия Скрипникова,

Национальный университет обороны Украины имени Ивана Черняховского

\section{Развитие межкультурной компетентности в психолого-педагогической теории и практике (зарубежный опыт)}

B статье раскрыты особенности развития межкультурной компетентности в роботах зарубежных ученых, в частности американских и европейских. На основе анализа и обобщения опыта современных зарубежных ученых определены педагогические технологии обучения для эффективного развития межкультурной компетентности. Актуализировано необходимость разрешения проблемы развития межкультурной компетентности будущих магистров военного управления.

Изучение зарубежного опыта свидетельствует о необходимости интеграции межкультурного (поликультурного) компонента в профессиональную подготовку военных специилистов.

Ключевые слова: межкультурная компетентность; межкультурная коммуникация; межкультурный диалог; межкультурное взаимодействие; поликультурное образование; интерактивные технологии.

\section{SUMMARY}

Valeriia Skrypnikova, National Defense University of Ukraine named after Ivan Cherniakhovskii

\section{Development of intercultural competence in psychological and pedagogical theory and practice (foreign experience)}

Introduction. The article is intended to study and generalize the features of the development of intercultural competence in psychological and pedagogical theory and practice.

Purpose is to analyze foreign experience in the development of intercultural competence in psychological and pedagogical theory and practice, and on its basis to identify ways to implement models of intercultural competence in the scientific community of Ukraine and identify criteria for intercultural competence that need further development.

Methods. Induction, deduction, systematization and analysis theoretical sources on the problem of acquiring and developing intercultural competence.

Results. The article reveals the peculiarities of the development of intercultural competence in the works of foreign researchers, in particular American and European. The need to solve the problem of developing intercultural competence of future masters of military management is urgent. 
The analysis and study of foreign experience indicates the need to integrate the intercultural (multicultural) component in the training of military specialists.

Originality. The analysis of pedagogical practice of formation of intercultural competence of future masters of military management has determined that for its development it is expedient to use interactive technologies aimed at development of dialogue, cooperation, creation of free creative space, independent active cognitive activity, reflection, variability and flexibility of learning content. Modern military professionals for effective interaction in the international security environment must have developed intercultural competence acquired in the process of professional military education, which ensures readiness for international cooperation through knowledge of cultures, intercultural communication styles, distinguishing languages and cultures of the world, intercultural understanding and dialogue in a multicultural environment.

Conclusion. Based on the analysis of the work of foreign researchers, we note that for the development of intercultural competence of future military professionals, it is advisable to use interactive technologies aimed at developing dialogue, cooperation, creating a free creative space, independent active cognitive activity, reflection, variability and flexibility of learning content.

Key words: intercultural competence; intercultural communication; intercultural dialogue; intercultural interaction; multicultural education; interactive technologies. 